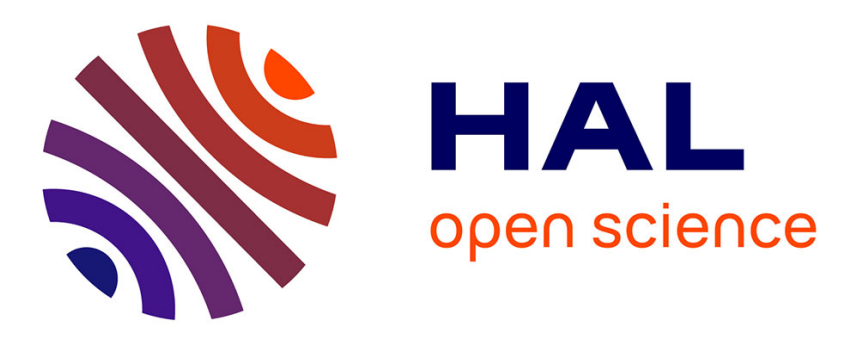

\title{
Analysis of roll gap heat transfers in hot steel strip rolling through roll temperature sensors and heat transfer models
}

\author{
Daniel Weisz-Patrault, Alain Ehrlacher, Nicolas Legrand, Nathalie Labbe, \\ Jaroslav Horsky, Tomas Luks
}

\section{To cite this version:}

Daniel Weisz-Patrault, Alain Ehrlacher, Nicolas Legrand, Nathalie Labbe, Jaroslav Horsky, et al.. Analysis of roll gap heat transfers in hot steel strip rolling through roll temperature sensors and heat transfer models. Key Engineering Materials, 2012, 504-506, pp.1043-1048. 10.4028/www.scientific.net/KEM.504-506.1043 . hal-00668233

\section{HAL Id: hal-00668233 \\ https://hal-enpc.archives-ouvertes.fr/hal-00668233}

Submitted on 9 Feb 2012

HAL is a multi-disciplinary open access archive for the deposit and dissemination of scientific research documents, whether they are published or not. The documents may come from teaching and research institutions in France or abroad, or from public or private research centers.
L'archive ouverte pluridisciplinaire HAL, est destinée au dépôt et à la diffusion de documents scientifiques de niveau recherche, publiés ou non, émanant des établissements d'enseignement et de recherche français ou étrangers, des laboratoires publics ou privés. 


\title{
Analysis of roll gap heat transfers in hot steel strip rolling through roll temperature sensors and heat transfer models
}

\author{
N. Legrand ${ }^{1, a}$, N. Labbe ${ }^{1, b}$ D. Weisz-Patrault ${ }^{2, .}$, \\ A. Ehrlacher ${ }^{2, d}$, T. Luks ${ }^{3, e}$, J. Horsky ${ }^{3, t}$ \\ ${ }^{1}$ ArcelorMittal Maizières Research, Maizieres-les-Metz, France \\ ${ }^{2}$ U.R. Navier, Ecole des Ponts et Chaussées, Marne la Vallée, France \\ ${ }^{3}$ Brno University of Technology, Brno, Czech republic \\ anicolas.legrand@arcelormittal.com, ${ }^{b}$ nathalie.labbe@arcelormittal.com, ${ }^{c}$ daniel.patrault@enpc.fr, \\ alain.ehrlacher@enpc.fr, ${ }^{e} l u k s @ L P T a P . f m e . v u t b r . c z$, 'horsky@fme.vutbr.cz
}

Keywords: hot strip rolling, roll bite heat transfer, inverse thermal analysis, thermal fatigue

\begin{abstract}
This paper presents an analysis of roll bite heat transfers during pilot hot steel strip rolling. Two types of temperature sensors (drilled and slot sensors) implemented near roll surface are used with heat transfer models to identify interfacial heat flux, roll surface temperature and Heat Transfer Coefficient $H T C_{\text {roll-bite }}$ in the roll bite. It is shown that:

- the slot type sensor is more efficient than the drilled type sensor to capture correctly fast roll temperature changes and heat fluxes in the bite during hot rolling but its life's duration is shorter.

- average $\mathrm{HTC}_{\text {roll-bite }}$ is within the range $15-26 \mathrm{~kW} / \mathrm{m}^{2} / \mathrm{K}$ : the higher the strip reduction (e.g. contact pressure) is, the higher the $\mathrm{HTC}_{\text {roll-bite }}$ is.

- scale thickness at strip surface tends to decrease heat transfers in the bite from strip to roll.

- HTC $_{\text {roll-bite }}$ is not uniform along the roll-strip contact but seems proportional to contact pressure.

- this non uniform $\mathrm{HTC}_{\text {roll-bite }}$ along the contact could contribute to decrease thermal shock (so roll thermal fatigue) when the work roll enters the roll bite, in comparison to a uniform $\mathrm{HTC}_{\text {roll-bite }}$.

- Heat transfer in the roll bite is mainly controlled by heat conduction due to the huge roll-strip temperature difference, while heat dissipated by friction at roll-strip interface seems negligible on these heat transfers.
\end{abstract}

\section{Introduction}

In hot rolling, thermal sollicitations of rolls are characterized by cyclic thermal shocks in the roll bite due to the cyclic contact between a strip at $\sim 1000^{\circ} \mathrm{C}$ and a roll at $50-100^{\circ} \mathrm{C}$. This cyclic thermal loading, amplified with work roll water cooling, is responsible for roll degradation by thermal fatigue that strongly shorten rolls life. A decrease of roll thermal fatigue requires a better knowledge of real peaks of temperature and heat transfers in the roll bite that are the source of the roll thermal shock. Currently, these roll bite peaks are approximated with Heat Transfer Coefficients 'HTC' macroscopically tuned on measured mill data. This current way of identification is sufficient to optimize mill cooling capacity where only a knowledge of the average heat transfer within and from the roll is needed. However, to determine roll degradation by thermal fatigue, an accurate and local evaluation of these roll bite peaks of temperature and heat transfers is necessary: this is the first aim of this paper. Furthermore, a huge amount of literature work has been focused on HTC and heat flux identification by inverse models during hot rolling [1]. However, the long computing time associated to these models does not allow a real time interpretation of measurements necessary for on line control of rolling mills. The second aim of this paper is thus to show the applicability of fast models for heat transfers identification quasi in real time. 


\section{Hot pilot mill trials}

Roll temperature sensors (fig.1) Roll temperature sensors are manufactured with K-type thermocouples implemented in a cylindrical plug. The work roll is drilled with one axial hole and 4 radial holes, then the plugs are inserted and glued into the different radial holes (fig.1a). The surface of the roll is finally regrinded to limit marks on the strip during rolling. The thermocouple is placed at a certain distance from roll surface $(\sim 0.5 \mathrm{~mm})$ to measure roll temperature at an inner roll radius. Moreover, the thermocouple wire is placed parallel to roll surface (and not perpendicular) to avoid perturbations of isotherms. Two different temperature sensors have been used:

- slot temperature sensor (fig.1b): the thermocouple is placed in a slot made by milling at the surface of the plug and brazed to the rest of the plug. A solder material (Nickel) covers the thermocouple. This sensor has a fast response time because the thermocouple is inserted in the continuum solder material (no empty and no air inside), but can be damaged easily during rolling.

- drilled temperature sensor (fig.1c) : the thermocouple is placed in a drilled hole remaining empty, e.g. containing air which is a strong thermal insulator. Consequently, the thermal response of that sensor is generally slower than the slot sensor but its mechanical resistance is generally higher.

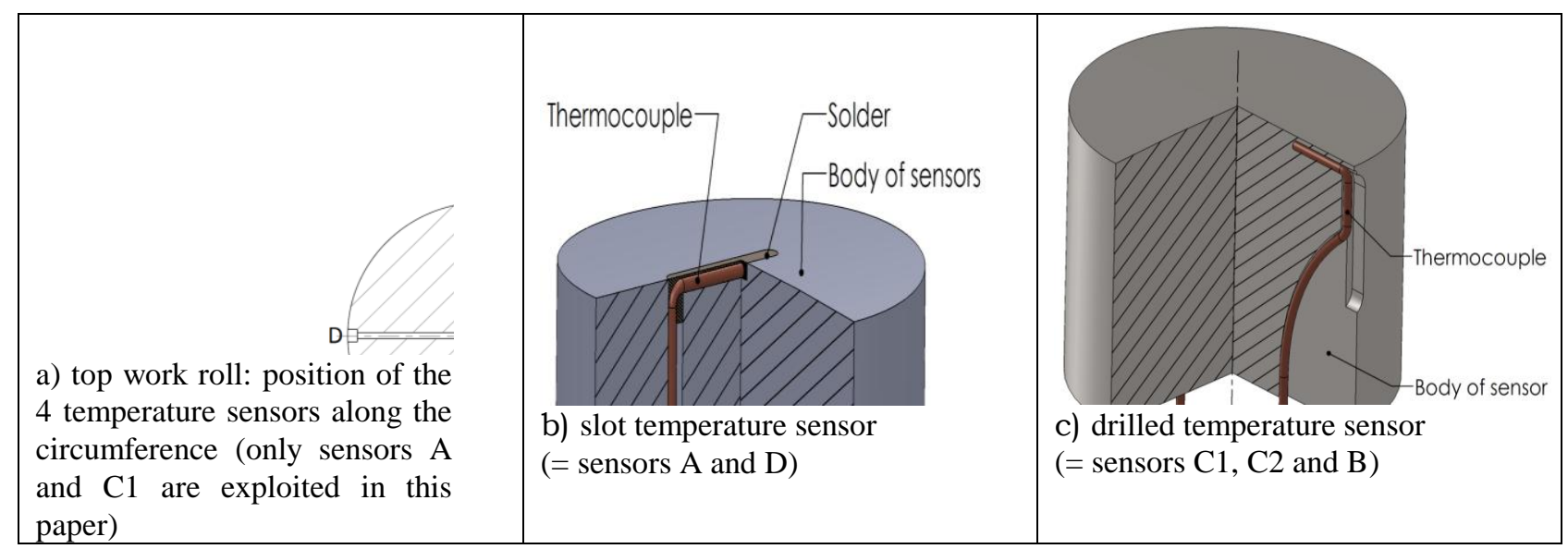

Fig. 1: temperature sensors

Pilot mill trials conditions. Aluminium killed grade strips (initial width/thickness = $100 \mathrm{~mm} / 60 \mathrm{~mm}$ ) were rolled on a hot pilot mill in 2-high configuration with the top work roll equipped with slot and drilled temperature sensors (work roll outer radius $=234.5 \mathrm{~mm}$ ). The distance $\mathrm{d}$ of the slot sensor ' $\mathrm{A}$ ' and the drilled sensor $\mathrm{C} 1$ have been evaluated respectively to 0.51 $\mathrm{mm}$ and $0.58 \mathrm{~mm}$ under roll surface with a calibration procedure using hot water sprayed on each sensor [2]: inner roll radius $=$ outer roll radius - sensor's distance to roll surface. Temperature signals during rolling have been stored using a data acquisition system (16 bits-sampling frequency: $3-5 \mathrm{kHz})$.

The roll was cooled by air outside the roll bite (no water cooling) and heated by the strip inside the roll bite. In comparison to a rolling configuration with water cooling, this rolling condition has the advantage to be simpler: only the heat transfer coefficient in the bite $\mathrm{HTC}_{\text {roll-bite }}$ is unkown and must be tuned with experiments. Heat transfer with air is relatively well known: $\mathrm{HTC}_{\mathrm{air}}=50 \mathrm{~W} / \mathrm{m} 2 / \mathrm{K}$.

Pilot mill trials results. Rolling test results are reported in table 1 and roll temperature evolution measured with slot and drilled sensors during successive rotations are shown on Fig.2. The response of the drilled sensor $\mathrm{C} 1$ is slower and smaller than the one of the slot sensor A, though both sensors are located at a similar distance from roll surface: $\sim 0.5 \mathrm{~mm}$. This slower response comes from the air contained in the drilled sensor (fig.1c) which acts as a strong thermal insulator, as confirmed by figure 5 . 


\begin{tabular}{|c|c|c|c|c|c|c|c|}
\hline \multicolumn{7}{|c|}{ Table 1: Pilot hot rolling test results } & \multirow{29}{*}{$\begin{array}{l}\text { Fig. } 2 \text { : roll temperature evolution measured with } \\
\text { slot sensor A and drilled sensor } C 1 \text { (test } n^{\circ} 10 \\
1^{\text {st }} \text { pass) }\end{array}$} \\
\hline test no & $\begin{array}{c}\text { reduction } \\
{[" \%]}\end{array}$ & $\begin{array}{l}\text { Roll Force } \\
{[\mathrm{kNN}]}\end{array}$ & $\begin{array}{c}\text { roll speed } \\
\text { [mps] }\end{array}$ & \begin{tabular}{|c}
$\begin{array}{c}\text { heating } \\
\text { fuanace } \\
\text { temperature } \\
{\left[{ }^{\circ} \mathrm{C}\right]}\end{array}$ \\
\end{tabular} & \begin{tabular}{|c} 
strip \\
temperature \\
(pyrometer \\
1 \\
{$\left[\begin{array}{c}1 \\
{[\mathrm{C}]}\end{array}\right.$} \\
\end{tabular} & \begin{tabular}{|c|c} 
strip \\
temperature \\
(pyrometer 2) \\
{$\left[\begin{array}{c} \\
{[\mathrm{C}]}\end{array}\right.$}
\end{tabular} & \\
\hline $\begin{array}{c}1 \\
\text { pass } 1\end{array}$ & 517 & & & 1150 & . & & \\
\hline $\begin{array}{l}\text { pass } 1 \\
\text { pass } 2\end{array}$ & $\frac{5.17}{5.10}$ & $\frac{207}{249}$ & $\frac{1.5}{1.5}$ & & $\frac{1100}{1053}$ & $\frac{1060}{1042}$ & \\
\hline pass 3 & 3.85 & 215 & 1.5 & & 1043 & 1022 & \\
\hline pass 4 & 3.79 & 228 & 1.5 & & 1029 & 1013 & \\
\hline pass 5 & 3.99 & 230 & 1.5 & & 1020 & 995 & \\
\hline 2 & & & & 1150 & & & \\
\hline pass 1 & 9.94 & 264 & 1.5 & & 1103 & 1076 & \\
\hline $\begin{array}{l}\text { pass } 2 \\
\text { pass } 3 \\
\end{array}$ & $\begin{array}{l}9.10 \\
11.94\end{array}$ & 298 & 1.5 & & $\frac{1055}{1040}$ & $\frac{1059}{079}$ & \\
\hline pass 4 & $\frac{11.94}{9.58}$ & 355 & $\frac{1.5}{15}$ & & $\frac{1040}{1030}$ & $\frac{979}{1004}$ & \\
\hline 3 & & & & 1150 & & & \\
\hline pass 1 & 14.64 & 339 & 1.5 & & 1117 & 1060 & \\
\hline pass 2 & 15.36 & 394 & 1.5 & & 1030 & 1024 & \\
\hline pass 3 & 13.92 & 380 & 1.5 & & 1020 & 1010 & \\
\hline pass 4 & 15.77 & 429 & 1.5 & & 1002 & 990 & \\
\hline 4 & & & & 1150 & & & \\
\hline pass 1 & 19.28 & 429 & 1.5 & & 1083 & 1000 & \\
\hline pass 2 & 20.17 & 525 & 1.5 & & 995 & 987 & \\
\hline pass 3 & 17.45 & 631 & 1.5 & & 965 & 927 & \\
\hline pass 4 & 19.09 & 592 & 1.5 & & 930 & 920 & \\
\hline 6 & & & & 1050 & & & \\
\hline pass 1 & 18.61 & 597 & 1.5 & & 1027 & 955 & \\
\hline pass 2 & 20.07 & 680 & 1.5 & & 988 & 989 & \\
\hline pass 3 & 18.21 & 635 & 1.5 & & 973 & 920 & \\
\hline 10 & & & & 1150 & & & \\
\hline pass 1 & 18.93 & 517 & 1.5 & & 1063 & 979 & \\
\hline pass 2 & 20.15 & 600 & 1.5 & & 1000 & 990 & \\
\hline pass 3 & 18.33 & 550 & 1.5 & & 1000 & 960 & \\
\hline
\end{tabular}

\section{Heat transfer models}

2 different heat transfer and temperature models are used to exploit roll temperature sensors: - model $n^{\circ} 1$ : a 2D semi-analytical temperature evolution model [2-3] (computing time for one roll revolution $\sim 0.2 \mathrm{~s}$.) is used in inverse mode: temperature measured with sensors at inner roll radius is used to predict interfacial heat flux and roll surface temperature. A 2D heat equation is solved for the roll (T: temperature, t: time, $r, \theta$ : roll position, $\omega$ : rotation speed, $\mathrm{D}$ : thermal diffusivity):

$$
\frac{\partial^{2} T}{\partial r^{2}}+\frac{1}{r} \cdot \frac{\partial T}{\partial r}+\frac{1}{r^{2}} \cdot \frac{\partial^{2} T}{\partial \theta^{2}}=\frac{1}{D}\left(\frac{\partial T}{\partial t}+\omega \frac{\partial T}{\partial \theta}\right)
$$

As the model is analytical, it considers thermal properties independent of temperature: $\lambda$ (thermal conductivity) $=17.3 \mathrm{~W} / \mathrm{m} / \mathrm{K}$ and $\mathrm{D}$ (thermal diffusivity) $=4.2 \mathrm{~mm} / \mathrm{sec}$. These values correspond to average thermal properties of solder material used in the slot sensor. For the drilled sensor, lower values are used $\left(\lambda=13 \mathrm{~W} / \mathrm{m} / \mathrm{K}, \mathrm{D}=2 \mathrm{~mm}^{2} / \mathrm{sec}\right.$.: fig.5) because of air in the sensor.

- model $n^{\circ}$ 2: a numerical finit difference roll gap heat transfer model for the strip coupled with a finit difference 1D roll temperature evolution model [4] is used in direct mode: the roll surface boundary condition $H T C_{\text {roll-bite }}$ is used as input of the roll temperature model to match predicted and measured temperatures at inner roll radius. The following 1D heat equation is solved for the roll:

$\frac{\partial^{2} T}{\partial r^{2}}+\frac{1}{r} \cdot \frac{\partial T}{\partial r}=\frac{1}{D}\left(\frac{\partial T}{\partial t}\right)$

The model can consider heat dissipation by friction in the bite and roll thermal properties dependent on temperature: $\lambda$ varies from 44 to $38 \mathrm{~W} / \mathrm{m} / \mathrm{K}$ and $\mathrm{D}$ varies from 11 to $8 \mathrm{~mm}^{2} / \mathrm{sec}$. for temperature varying from 20 to $350^{\circ} \mathrm{C}$. These values correspond to thermal properties of a normal steel grade which is the grade used for the work rolls. Model $\mathrm{n}^{\circ} 2$ cannot consider the sensor in the work roll, in contrast to model $n^{\circ} 1$, however, it has been checked that the difference of roll thermal properties used in the two models has not a significant influence on results, except for the drilled sensor (fig.5). Finally the difference of heat equations (2D: model $n^{\circ} 1,1 D$ : model $n^{\circ} 2$ ) on results of the two models is discussed on fig.7. 


\section{Evaluation of roll surface temperature and heat flux by inverse calculation $\left(\operatorname{model} \mathrm{n}^{\circ} \mathbf{1}\right)$}

Influence of strip reduction. Fig. 3 shows for different strip reductions $(5 \%, 10 \%, 15 \%, 20 \%)$ the evolution of roll temperature measured at the inner roll radius during rolling and the reconstructed interfacial heat flux and roll surface temperature at the outer roll radius with inverse model $\mathrm{n}^{\circ} 1$ : the higher the strip reduction is, the higher the surface temperature and heat flux from strip to roll in the bite are. This trend is due to the higher heat dissipated by plastic deformation corresponding to the higher strip reductions.

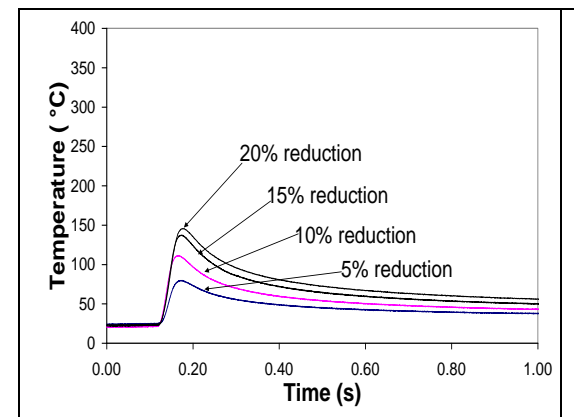

a) Measured temperature at inner roll radius

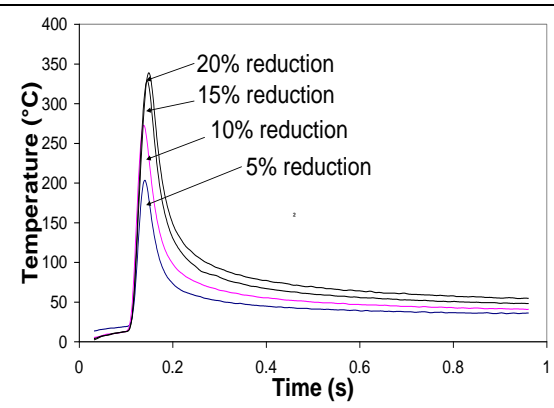

b) Reconstructed temperature at outer roll radius (surface)

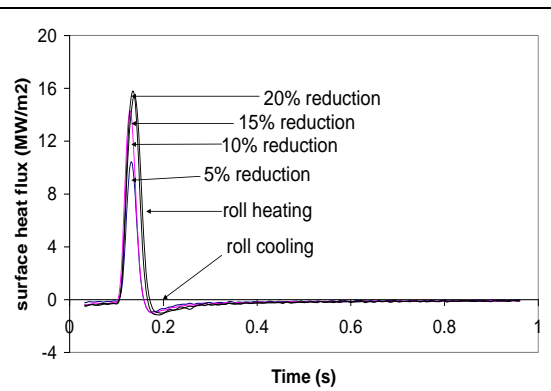

c) Reconstructed heat flux at outer roll radius (surface)

Fig.3: strip reduction influence on heat flux and surface temperature (tests $n^{\circ} 1$ to $4-1^{\text {st }}$ pass, $1^{\text {st }}$ revolution, sensor $\mathrm{A}$ )

Influence of strip surface scale. Fig. 4 shows the reconstruction by inverse model $\mathrm{n}^{\circ} 1$ of temperature and heat flux at roll surface (using the measured temperature at inner roll radius, not shown here) for the two different furnace temperatures at which the strip has been heated prior to rolling: $1050^{\circ} \mathrm{C}$ (test $\mathrm{n}^{\circ} 6$ ) and $1150^{\circ} \mathrm{C}$ (test $\mathrm{n}^{\circ} 10$ ). The higher the heating furnace temperature is, the lower the roll bite heat flux is.

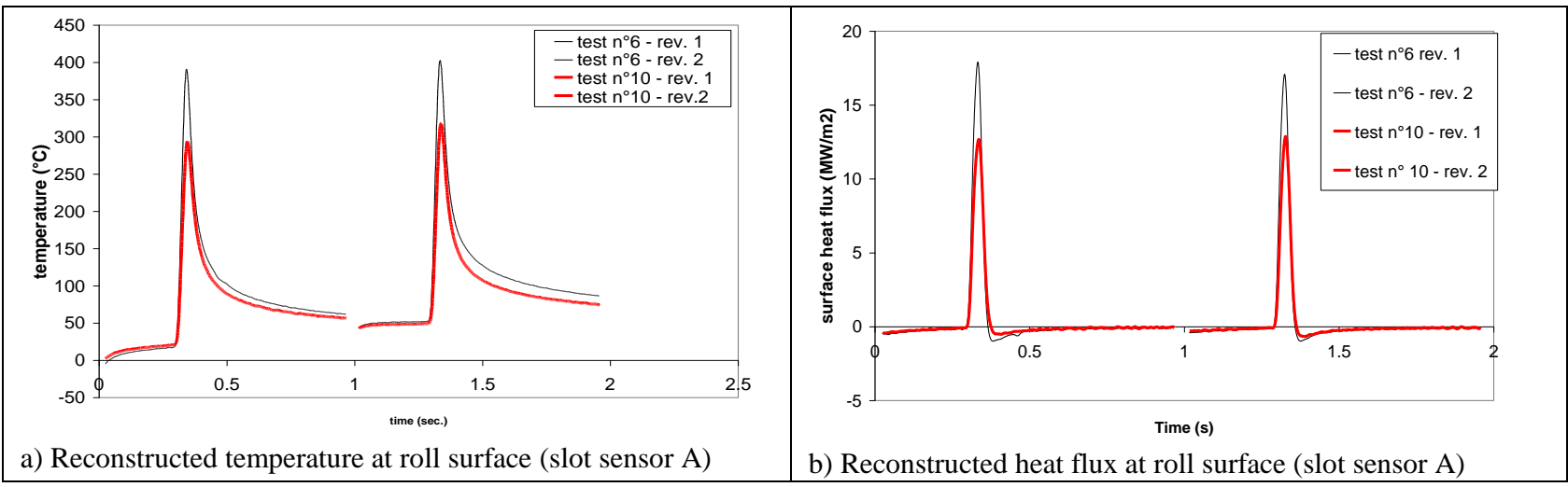

Fig.4: influence of strip surface scale on roll surface temperature and surface heat flux for two different furnace temperatures: $1050^{\circ} \mathrm{C}$ and $1150^{\circ} \mathrm{C}$ (tests $\mathrm{n}^{\circ} 6$ and $10-1^{\text {st }}$ pass $-21^{\text {st }}$ revolutions)

A model has been used to determine the scale thickness formation for the two tests $n^{\circ} 6$ and $n^{\circ} 10$ : - test $\mathrm{n}^{\circ} 6$ : strip pre-heated at $1050^{\circ} \mathrm{C}$ has produced a scale thickness of $\sim 35 \mu \mathrm{m}$ at strip surface.

- test $n^{\circ} 10$ : strip pre-heated at $1150^{\circ} \mathrm{C}$ has produced a scale thickness of $\sim 60 \mu \mathrm{m}$ at strip surface.

As scale has a much lower thermal conductivity $(2 \mathrm{~W} / \mathrm{m} / \mathrm{K})$ than steel $(15 \mathrm{~W} / \mathrm{m} / \mathrm{K})$, the thicker scale thickness in test $\mathrm{n}^{\circ} 10$ acts as a thermal insulator, decreasing roll-strip heat transfers.

Evaluation of roll surface temperature and heat flux using slot and drilled sensors. Fig. 5 shows heat flux and roll surface temperature reconstructed with drilled and slot sensors respectively using the inverse model $n^{\circ} 1$. For the reconstruction with the slot sensor, the thermal properties of the solder material were used: $\lambda=17.3 \mathrm{~W} / \mathrm{m} / \mathrm{K}$ and $\mathrm{D}=4.2 \mathrm{~mm}^{2} / \mathrm{sec}$. For the reconstruction with the drilled sensor, the thermal properties $\lambda$ and $\mathrm{D}$ have been adjusted to obtain a similar curve as for the slot sensor: $\lambda=13 \mathrm{~W} / \mathrm{m} / \mathrm{K}$ and $\mathrm{D}=2 \mathrm{~mm} / \mathrm{sec}$. were obtained. These lower values are consistent 
with the air contained in the drilled sensor that slows down heat exchanges with the sensor. Nevertheless due to these heat exchanges modified by air, the reconstruction at roll surface with the drilled sensor presents much more noise than the reconstruction with the slot sensor, especially for heat transfer reconstruction. The slot sensor is thus more efficient than the drilled sensor.

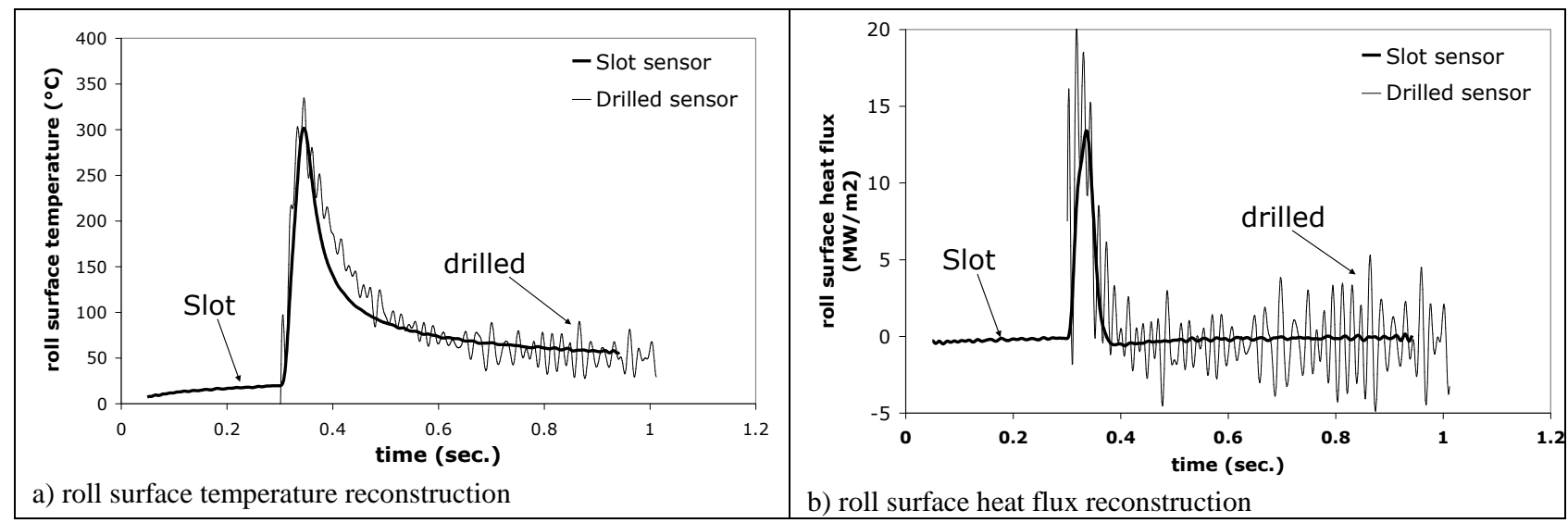

Fig.5: roll surface temperature and heat flux reconstructed with slot and drilled sensors respectively (test $n^{\circ} 10-1^{\text {st }}$ pass, revolution $n^{\circ} 1$ )

\section{Evaluation of roll surface temperature and $\mathrm{HTC}_{\text {roll-bite }}$ by direct calculation $\left(\operatorname{model} \mathbf{n}^{\circ} 2\right)$}

Heat Transfer Coefficient evaluation (HTC). $\mathrm{HTC}_{\text {roll-bite }}$ is adjusted by direct calculations to match measured and simulated roll temperatures at inner roll radius for test $n^{\circ} 6,1^{\text {st }}$ pass, $1^{\text {st }}$ revolution: $\mathrm{HTC}_{\text {roll-bite }}$ was identified approximately to $20 \mathrm{~kW} / \mathrm{m}^{2} / \mathrm{K}$ for test $\mathrm{n}^{\circ} 10$ (fig.6a shows the identification) and to $26 \mathrm{~kW} / \mathrm{m} 2 / \mathrm{K}$ for test $\mathrm{n}^{\circ} 6$.

Evaluation of temperature response for slot and drilled sensors. For test $n^{\circ} 10$, fig. $6 a$ and $6 b$ compare at the inner roll radius the temperature measured with the two sensors with the temperature predicted by the model $\mathrm{n}^{\circ} 2$ assuming an homogeneous material.

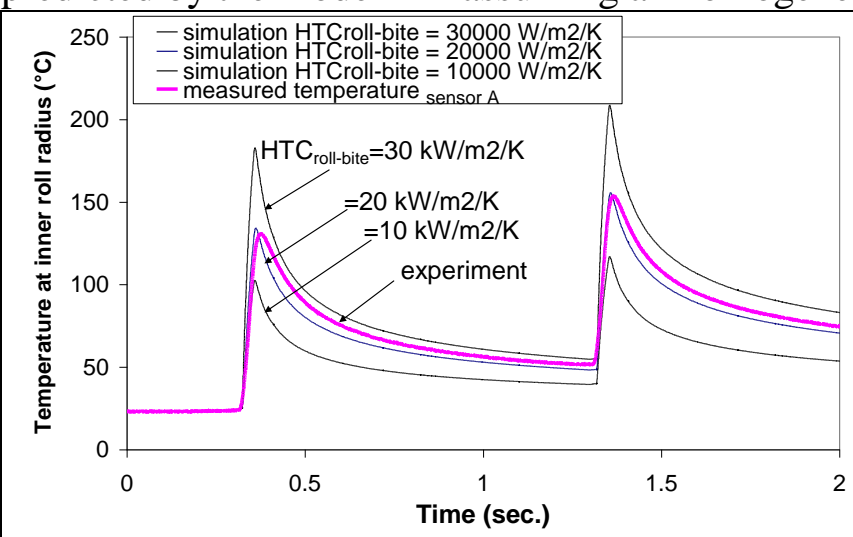

a) experiment: slot sensor $\mathrm{A}-\mathrm{d}=0.51 \mathrm{~mm}-\mathrm{HTC}_{\text {roll-bite }}$ identification

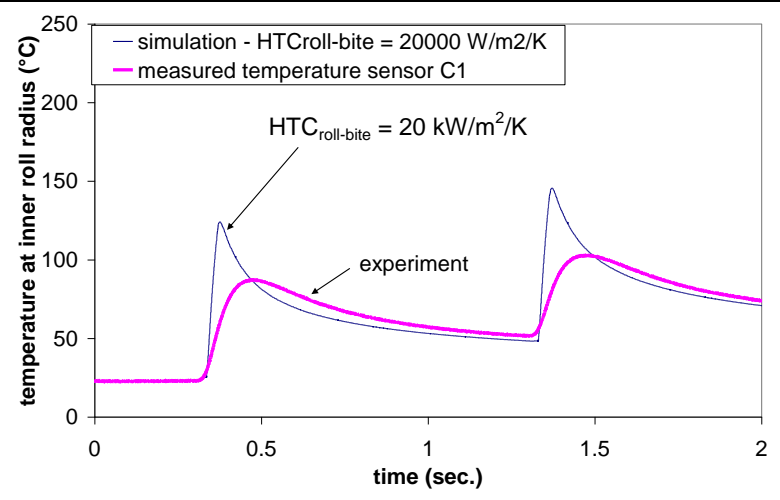

b) experiment: drilled sensor $\mathrm{C} 1-\mathrm{d}=0.58 \mathrm{~mm}-$ simulated inner roll radius temperature using $\mathrm{HTC}_{\text {roll bite }}$ identified with sensor A compared with experiment

Fig.6: comparison of simulated and measured temperature responses with slot sensor A and drilled sensor $\mathrm{C} 1$ (test $^{\circ} 10,1^{\text {st }}$ pass, two $1^{\text {st }}$ revolutions, high scale thickness : $~ 60$ microns)

The slot type sensor do not perturb the measured temperature field and can capture correctly the fast roll temperature change when passing through the roll bite (fig.6a), but life's duration of the slot sensor is shorter than the drilled sensor. The drilled sensor perturb the measured temperature field when passing through the roll bite, this is due to the air contained in it that acts as thermal insulator but its life duration is longer (fig. 6b). These results are consistent with the ones of fig.5.

HTC $_{\text {roll-bite }}$ as a function of strip surface scale. $\mathrm{HTC}_{\text {roll-bite }}$ as a function of strip surface scale thickness can be identified by comparison of test $n^{\circ} 6$ (small scale thickness $\sim 35$ microns: HTC $_{\text {roll-bite }}$ $=26 \mathrm{~kW} / \mathrm{m}^{2} /{ }^{\circ} \mathrm{K}$ ) with test $\mathrm{n}^{\circ} 10$ (higher scale thickness $\sim 60$ microns: fig. $6 \mathrm{a}: \mathrm{HTC}_{\text {roll-bite }}=20$ $\left.\mathrm{kW} / \mathrm{m}^{2} /{ }^{\circ} \mathrm{K}\right)$. 
HTC $_{\text {roll-bite }}$ as a function of strip reduction. $\mathrm{HTC}_{\text {roll-bite }}$ has been identified as a function of strip reduction using tests $n^{\circ} 1$ to 4 (Fig. 7a): the higher the strip reduction is, the higher the average $\mathrm{HTC}_{\text {roll-bite }}$ is, with a saturation around $20 \%$.

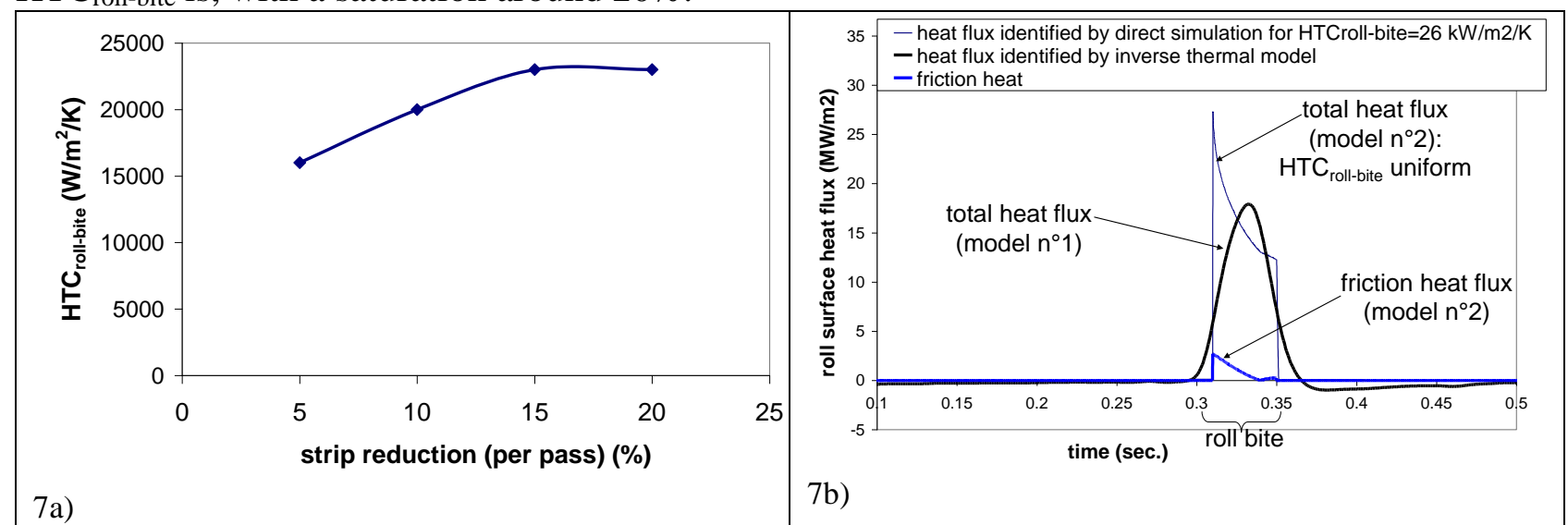

Fig.7: $\mathrm{HTC}_{\text {roll-bite }}$ identification as a function of strip reduction (left: tests $\mathrm{n}^{\circ} 1$ to 4 ) and interfacial heat flux identified with models $n^{\circ} 1$ and $n^{\circ} 2$ (right: test $n^{\circ} 6$ ) (slot sensor $\mathrm{A}$ )

Comparison of interfacial heat flux reconstructed with model $n^{\circ} 2$ and with inverse model $\mathbf{n}^{\circ} \mathbf{1}$. For test $\mathrm{n}^{\circ} 6$, fig. $7 \mathrm{~b}$ shows a comparison of the interfacial heat flux determined by direct simulation with model $\mathrm{n}^{\circ} 2$ using a uniform $\mathrm{HTC}_{\text {roll-bite }} 26 \mathrm{~kW} / \mathrm{m}^{2} / \mathrm{K}$ (value obtained as for fig. 6a) with the interfacial heat flux determined with the inverse model $\mathrm{n}^{\circ} 1$ using directly temperature sensors. The bad agreement between the two interfacial heat fluxes can be due to $\mathrm{HTC}_{\text {roll-bite }}$ assumed uniform in model $\mathrm{n}^{\circ} 2$ while it seems not uniform but proportional to roll gap pressure according to model $\mathrm{n}^{\circ} 1$. Moreover, the absence of peak of heat flux at bite entry obtained with model $n^{\circ} 1$ suggests that the real thermal fatigue submitted by the roll could be lower in comparison to the one determined with model $\mathrm{n}^{\circ} 2$. Furthermore, fig. $7 \mathrm{~b}$ shows that heat flux dissipated by friction is negligible compared to the conduction heat flux. Finally fig. $7 \mathrm{~b}$ shows that at the exit of the roll bite, heat flux is reversed (change direction) with model $n^{\circ} 1$ while it remains strictly zero for model $n^{\circ} 2$ : it is suspected that this difference is due the different heat equation used in the two models (2D heat equation for model $\mathrm{n}^{\circ} 1$, $1 \mathrm{D}$ heat equation for model $\mathrm{n}^{\circ} 2$ ). Additional work is needed to further investigate the above conclusions, it is scheduled in a future work.

\section{Conclusions}

Roll bite heat transfers and roll temperature distribution have been identified with roll temperature sensors combined with models. With this identification, it is now possible to evaluate precisely the corresponding roll thermal fatigue during rolling. It is scheduled in a future work.

\section{References}

[1] P.Kotrbacek, M. Raudensky, J. Horsky, M. Pohanka, Experimental study of heat transfer and heat flux by inverse analysis during steel strip rolling, Revue de metalurgie 103 (2006) 333-341.

[2] D. Weisz-Patrault, A. Ehrlacher, N. Legrand, N. Labbe,J.Horsky, T.Luks. Experimental study of interfacial heat flux and surface temperature by inverse thermal analysis with thermocouple (fully embedded) during hot steel strip rolling. Advanced Materials Research 452-453 (2012) 959-963

[3] D. Weisz-Patrault, A. Ehrlacher, N. Legrand, Evaluation of temperature field and heat flux by inverse analysis during steel strip rolling. Int. J. of Heat and Mass Transfer 55 (2012) 629-641

[4] User's manual of Cylescale, roll and strip temperature evolution model - internal report ArcelorMittal (2009) 